\title{
I Indium Hybridization of Large Format TES Bolometer Arrays to Readout Multiplexers for Far-Infrared Astronomy
}

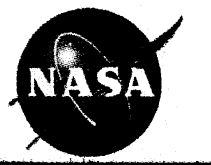

Timothy M. Milier, a,b Nick Costen, ${ }^{a, b}$ Christine Allen"

-NASA Goddard Space Fllght Center, Code 553, 8800 Greenbelt Rd., Greenbelt, MD 20771, USA bMEI Technologles Inc., 7404 Executive Place, Sulte 500, Seabrook, MD 20706, USA

SOFLA Vision 2020, Pasadena, Callfornla. Dec. 6-8, 2007

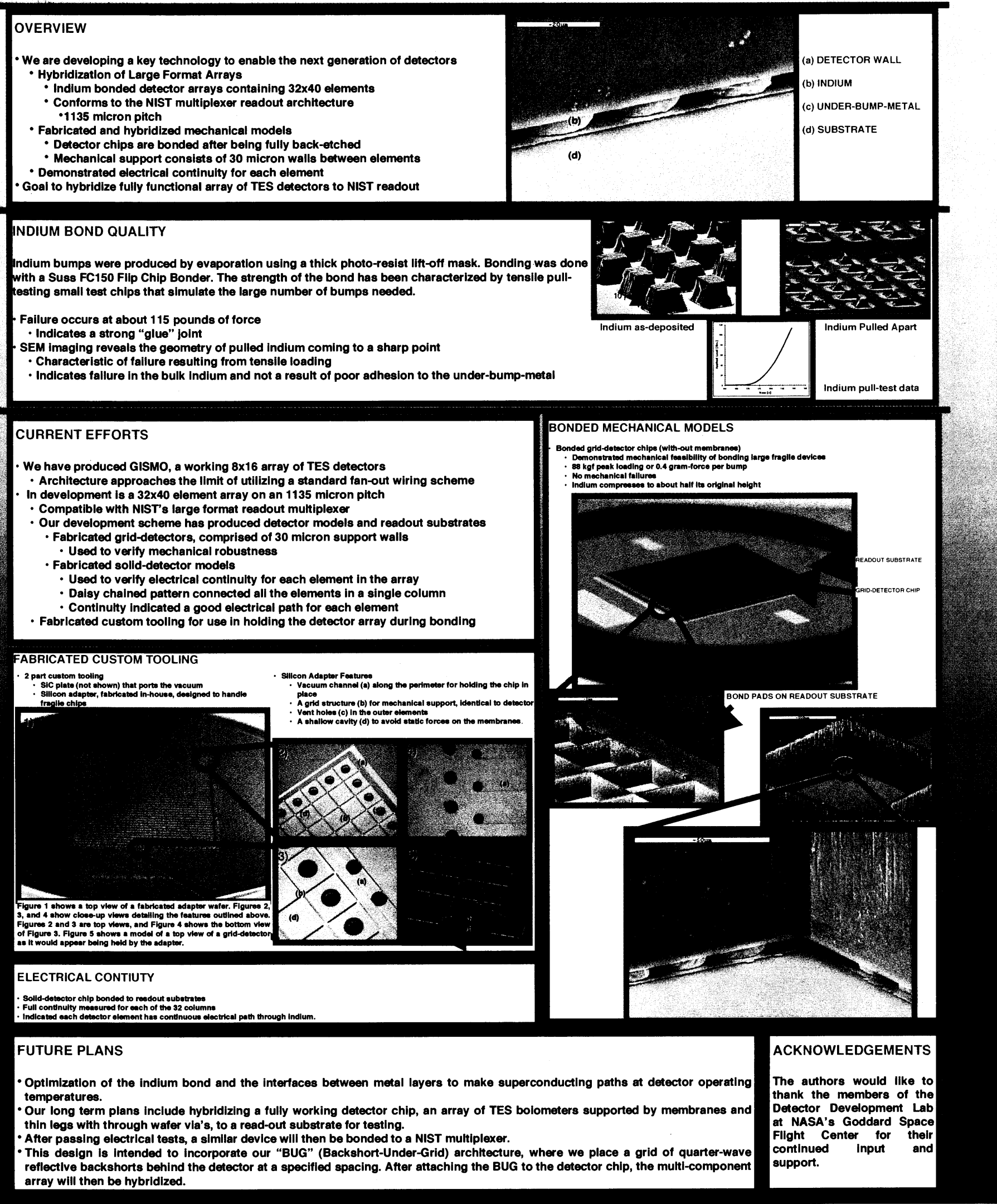

